\title{
BMJ Open Association between exposure in the cement production industry and non-malignant respiratory effects: a systematic review
}

\author{
Anne Kristin Møller Fell, ${ }^{1}$ Karl Christian Nordby ${ }^{2}$
}

To cite: Fell AKM, Nordby KC. Association between exposure in the cement production industry and non-malignant respiratory effects: a systematic review. BMJ Open 2017;7:e012381. doi:10.1136/bmjopen-2016012381

- Prepublication history for this paper is available online. To view these files please visit the journal online (http://dx.doi.org/10.1136/ bmjopen-2016-012381).

Received 4 May 2016 Revised 2 March 2017 Accepted 6 March 2017

CrossMark

\footnotetext{
${ }^{1}$ Department of Occupational and Environmental Medicine, Telemark Hospital, Skien, Norway

${ }^{2}$ National Institute of Occupational Health, Oslo, Norway
}

Correspondence to Dr Anne Kristin Møller Fell; annfel@sthf.no

\section{ABSTRACT}

Objectives: Based on findings from a systematic literature search, we present and discuss the evidence for an association between exposure to cement dust and non-malignant respiratory effects in cement production workers.

Design and setting: Systematic literature searches (MEDLINE and Embase) were performed. Outcomes were restricted to respiratory symptoms, lung function indices, asthma, chronic bronchitis, chronic obstructive pulmonary disease, pneumoconiosis, induced sputum or fraction of exhaled nitric oxide (FeNO) measurements. Participants: The studies included exposed cement production workers and non-exposed or low-exposed referents.

Primary and secondary outcomes: The searches yielded 594 references, and 26 articles were included. Cross-sectional studies show reduced lung function levels at or above $4.5 \mathrm{mg} / \mathrm{m}^{3}$ of total dust and $2.2 \mathrm{mg} / \mathrm{m}^{3}$ of respiratory dust. ORs for symptoms ranged from 1.2 to 4.8 , while $\mathrm{FEV}_{1} / \mathrm{FVC}$ was $1-6 \%$ lower in exposed than in controls. Cohort studies reported a high yearly decline in $\mathrm{FEV}_{1} / \mathrm{FVC}$ ranging from $0.8 \%$ to $1.7 \%$ for exposed workers. 1 longitudinal study reported airflow limitation at levels of exposure comparable to $\sim 1 \mathrm{mg} / \mathrm{m}^{3}$ respirable and $3.7-5.4 \mathrm{mg} / \mathrm{m}^{3}$ total dust. A dose-response relationship between exposure and decline in lung function has only been shown in 1 cohort. 2 studies have detected small increases in FeNO levels during a work shift; 1 study reported signs of airway inflammation in induced sputum, whereas another did not detect an increase in hospitalisation rates.

Conclusions: Lack of power, adjustment for possible confounders and other methodological issues are limitations of many of the included studies. Hence, no firm conclusions can be drawn. There are few longitudinal data, but recent studies report a doseresponse relationship between cement production dust exposure and declining lung function indicating a causal relationship, and underlining the need to reduce exposure among workers in this industry.

\section{INTRODUCTION}

Health effects associated with exposure to cement were reported by Bernardino
Strengths and limitations of this study

- Systematic searches in MEDLINE and Embase were performed, and the so-called 'grey literature' was assessed through Google Scholar.

- The Grading of Recommendations, Assessment, Development and Evaluations (GRADE) criteria or similar systems used to evaluate the quality of evidence was not applied, but elements used as evaluation criteria are presented according to study design, sample size, inclusion of controls, adjustment for covariates and relevant outcome variables.

- Many of the 15 cross-sectional studies did not include controls and/or adjust for smoking and 1 study did not include variance in the outcome estimates; thus, assessment of publication bias through a funnel plot was not performed.

- We restricted the review to studies reporting dust measurements, but comparison of exposure assessment between studies was not possible due to limited information regarding, the number of measurements sampling strategy and quality of measurements.

Ramazzini as early as 1700 . Some 250 years later, evidence of an association between the chromate sensitivity induced by cement exposure and dermatitis was reported. ${ }^{1}$ Since then, a substantial number of studies have reported increased prevalence of respiratory symptoms, reduced dynamic lung function, chronic bronchitis, emphysema, asthma and radiographic abnormalities of the lungs, although many of these studies have been hampered by limitations. ${ }^{2} 3$

The modern cement manufacturing process is based on crushing and grinding limestone with quartz or other sources of silica, iron ore and other additives. The mixture is fed into a rotating kiln with burning fuels, consisting of coal, natural gas, oil and/or alternative fuels (eg, household waste, car tyres) and the temperature is 
increased to $\sim 1450^{\circ} \mathrm{C}$. A series of chemical reactions causes the materials to fuse and form grey nodules called 'cement clinker'. The clinker is mixed with gypsum and other additives, and ground to a fine particulate powder to yield cement.

Portland cement, one of the most commonly used cements, is a mixture of calcium oxide $(60-67 \%)$, silicon dioxide $(17-25 \%)$, aluminium trioxide $(3-8 \%)$ and ferric oxide $(0-5 \%) .^{2}$ Cement production processing generates large amounts of dust during quarrying, grinding and when the finished cement is blended, packed and shipped. Our aim was to present and discuss the evidence for an association between exposure to cement production dust and non-malignant respiratory effects, and to recommend measures for exposure prevention.

\section{METHODS}

\section{Search}

Electronic databases were searched from inception to 4 November 2015. The databases MEDLINE and Embase were searched using the Ovid interface. In addition, the authors brought forward three other relevant publications for further review.

The search strategy was developed by the authors in close cooperation with search specialists at the libraries at Telemark Hospital in Skien and the National Institute of Occupational Health in Oslo, Norway. Key items (MeSH/Emtree terms) included: occupational exposure, work environment, workplace, worker, industrial worker, employment, factory, exposure cement industry, construction industry, cement factory, epidemiology, cement, clinker, concrete, mortar, Portland cement, occupational disease, occupational lung disease, symptom, respiratory tract disease, chronic obstructive pulmonary disease (COPD), respiratory failure, lung disease, lung function, asthma, obstructive lung disease, obstructive airway disease, bronchitis, allergy and hypersensitivity. The Boolean operators AND, OR and NOT were incorporated into the search terms. In addition, single terms were truncated and included as text words. The Clinical Queries filter for causation aetiology (best balance of sensitivity and specificity) was used.

We also searched the so-called 'grey literature' (references not indexed in medical databases such as MEDLINE and Embase) using Google Scholar and the search term: cement AND lung.

\section{Selection of published studies for review}

The following inclusion criteria were defined:

- Peer-reviewed articles.

- Languages: English, German, Danish, Swedish or Norwegian.

- Design: human studies; cross-sectional, case-control, retrospective or prospective cohort studies.

- Exposure: occupational exposure to cement production dust, and exposure measurements including information regarding how the measurements were obtained (individual or group).

- Outcome: respiratory symptoms, lung function indices, asthma, chronic bronchitis, COPD, pneumoconiosis, outcomes identified by analysis of induced sputum or fraction of exhaled nitric oxide $(\mathrm{FeNO})$ measurements.

- Data analysis: the analysis techniques must have been reported.

Studies meeting each of these inclusion criteria were reviewed. We used a two-level screening approach to evaluate the identified studies. First, titles and abstracts were screened for eligibility. This was performed independently by two reviewers (AKMF and KCN). Second, the full-text articles were evaluated. Agreement was reached in consensus meetings on the selection of fulltext articles and article inclusion.

The search strategy yielded 594 references. Of these, 56 full-text articles were selected for evaluation. Three relevant articles were added by the authors and assessed in the same manner as the others. Twenty-six articles met the inclusion criteria. Figure 1 shows the flow chart for study identification, screening, eligibility, inclusion and exclusion.

The Google Scholar search identified 170000 records, of which the first (most relevant) 400 was assessed by the first author, but none that had not already been identified or included by the authors met inclusion criteria.

\section{Quality of evidence}

A limited number of studies assessing the association between non-malignant respiratory effects and exposure to cement dust were anticipated. Thus, we decided not to use either the Grading of Recommendations, Assessment, Development and Evaluations (GRADE) criteria ${ }^{4}$ or any other similar system to evaluate the quality of evidence but instead summarise in the tables some of the elements used as evaluation criteria according to study design, as well as whether and how the study included evaluation of sample size, referents or lowexposed controls, adjustment for covariates, and relevant outcome variables.

\section{RESULTS}

The characteristics and findings from 15 cross-sectional and 11 cohort studies are summarised in tables 1 and 2, respectively.

\section{Cross-sectional studies}

Eight out of the 11 cross-sectional studies that included lung function measurements reported reduced lung function in exposed workers when compared with controls. One of the first studies that included dust measurements and adjusted for relevant cofactors was a large survey of US cement production workers $(\mathrm{N}=2736)$ and blue-collar controls $(\mathrm{N}=755) .{ }^{5}$ In that study, exposed 


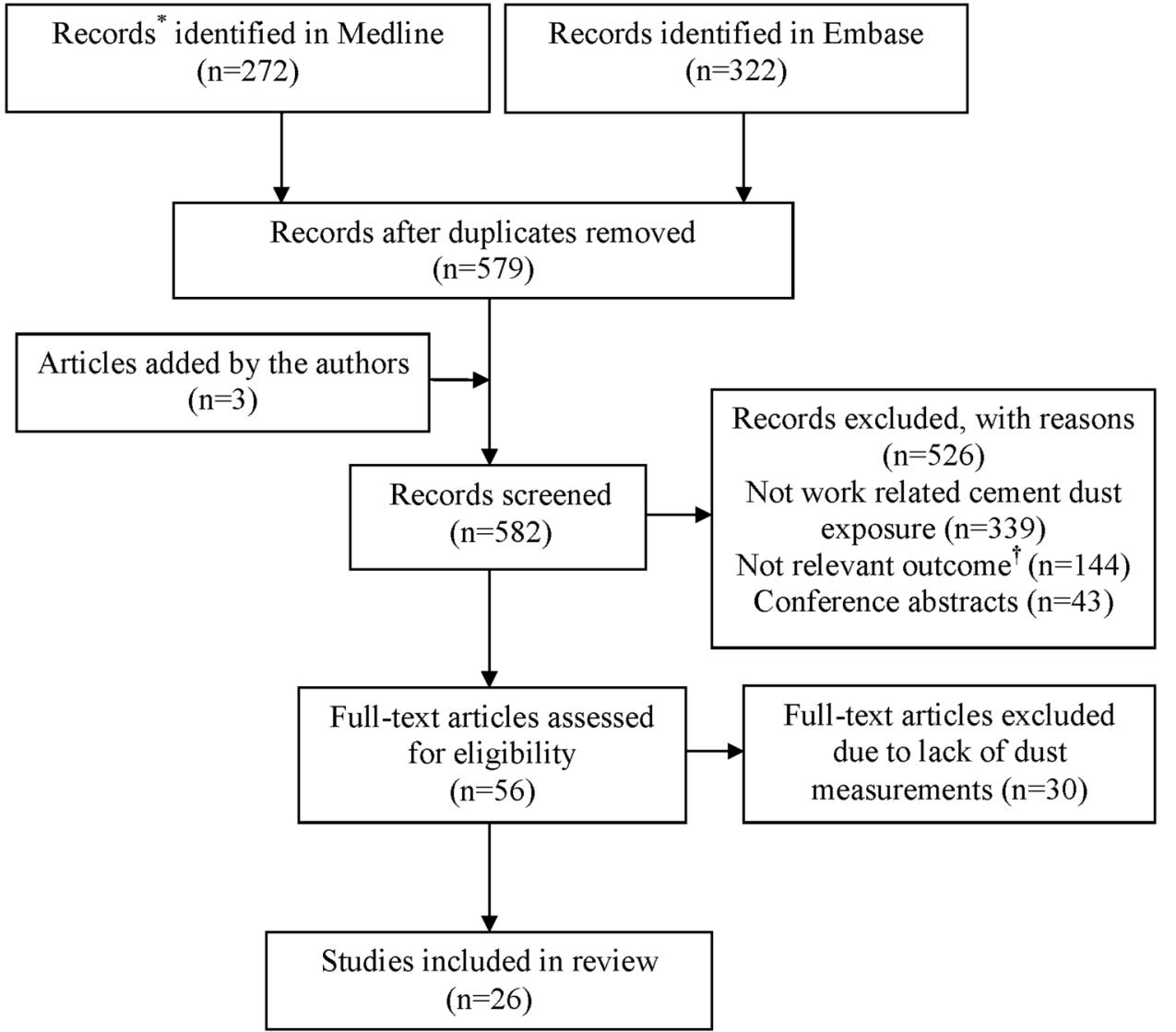

Figure 1 Identification, screening, eligibility and inclusion of studies on non-malignant respiratory effects of cement production dust from systematic searches in PubMed and Embase from November 2015. *Some articles are registered more than once in the databases; †based on the inclusion criteria for outcomes: respiratory symptoms, lung function indices, asthma, chronic bronchitis, chronic obstructive pulmonary disease, blood cell counts, measurement of levels of inflammatory markers in cells, serum, plasma or sputum or fraction of exhaled nitric oxide (FeNO) measurements.

workers and controls had similar prevalence rates of respiratory symptoms, except that the cement workers reported more dyspnoea compared with controls. Similar levels were also reported for the lung function indices.

In a small $(\mathrm{N}=48)$ Yugoslavian study from 1989, the levels of $\alpha_{1}$-antitrypsin (AAT) in serum, spirometry and single-breath transfer factor for carbon monoxide $\left(\mathrm{DL}_{\mathrm{CO}}\right)$ were measured. ${ }^{6} \mathrm{FVC}$ and $\mathrm{FEV}_{1}$ values were negatively related to duration of exposure, and a significant relationship was detected between AAT and respirable dust concentration. No reference group was included in that study. Another small study, restricted to non-smoking cement production workers and bluecollar controls in Malaysia, included 32 exposed workers. ${ }^{7}$ Nevertheless, that study detected a reduced $\mathrm{FEV}_{1} / \mathrm{FVC}$ ratio among the exposed when compared with the controls. A study from Taiwan (N=147) reported significantly elevated OR for cough: 1.6 (1.3 to 1.8), phlegm: 1.3 (1.1 to 1.5 ), wheezing: 1.2 (1.0 to 1.4 ) and dyspnoea: 1.2 (1.1 to 1.4) for cement production workers compared with office workers. ${ }^{8} \mathrm{FEV}_{1}$ was $2.7 \mathrm{~L}$ versus $3.0(p<0.05)$ and FVC $3.5 \mathrm{~L}$ versus $3.8(\mathrm{p}<0.05)$ in cases and controls, respectively.
A relatively large study from Jordan $(\mathrm{N}=348)$ did not find differences in symptoms or lung function indices between groups of cement production workers with low, medium and high exposure levels. ${ }^{9}$ In that study, adjustments for age and smoking were made, but no control group was included. A study undertaken in Saudi Arabia reported that wheezing and shortness of breath were related to cement dust exposure. ${ }^{10}$ A possible confounder in that study may be socioeconomic differences between the exposed group and the references who were office workers. In two studies from Tanzania, the prevalence of airway symptoms was higher in exposed workers than controls, ${ }^{11}$ and lower FVC, $\mathrm{FEV}_{1}, \mathrm{FEV}_{1}$ / FVC and peak expiratory flow (PEF) values ${ }^{12}$ were demonstrated in the cement production workers. In the first study, exposure assessment showed that a cumulative total dust exposure of more than $300 \mathrm{mg} / \mathrm{m}^{3} \times$ years was significantly associated with airflow limitation. In a third study from the same group, exposure $<2 \mathrm{mg} / \mathrm{m}^{3}$ was associated with cough OR 7.9 (1.8 to 35), and dyspnoea 4.2 (1.1 to 15$).{ }^{13}$ PEF showed a $4.5 \%$ decrease per unit log-transformed dust. In a more recent study from Tanzania, the fractional exhaled nitric oxide (FeNO) levels of cement production workers and controls were 
Table 1 Characteristics and main results of included cross-sectional studies assessing non-malignant respiratory disease and exposure to cement production dust

\begin{tabular}{|c|c|c|c|c|c|c|c|}
\hline Country & $\begin{array}{l}\text { Exposure metric } \\
\text { (number), personal } \\
\text { dust levels } \mathrm{mg} / \mathrm{m}^{3} \\
\text { (SD) }\end{array}$ & $\begin{array}{l}\text { Number of } \\
\text { exposed } \\
\text { workers } \\
\text { (response } \\
\text { rate, \%) }\end{array}$ & $\begin{array}{l}\text { Source of } \\
\text { controls }\end{array}$ & $\begin{array}{l}\text { Adjustment } \\
\text { for age and } \\
\text { smoking }\end{array}$ & $\begin{array}{l}\text { Main effects respiratory } \\
\text { symptoms and other findings: } \\
\text { OR }(95 \% \mathrm{Cl}) \text { or percentage (SD) } \\
\text { exposed vs non-exposed, } \\
\text { p value }\end{array}$ & $\begin{array}{l}\text { Main effects lung function } \\
\text { tests: OR }(95 \% \mathrm{Cl}) \text { or } \\
\text { percentage (SD) exposed } \\
\text { vs non-exposed, } p \text { value } \\
\end{array}$ & Reference \\
\hline USA & $\begin{array}{l}\text { Total dust }(211): 2.9, \\
\text { range: } 0.01-79, \\
\text { respirable dust } \\
\text { (1011): } 0.6 \text { range: } \\
0.01-46.2\end{array}$ & $2736(87)$ & Blue-collar workers & Yes & OR for dyspnoea: $1.6(p=0.05)$ & $\begin{array}{l}\text { NS differences in lung } \\
\text { function indices }\end{array}$ & 5 \\
\hline Yugoslavia & $\begin{array}{l}\text { Total (NR): range: } \\
6.5-230 \text {, respirable } \\
\text { (NR): } 2.2-46\end{array}$ & $48(100)$ & None & Yes & Not reported (NR) & $\begin{array}{l}\mathrm{FVC} \text { and } \mathrm{FEV}_{1} \text { levels } \\
\text { negatively related to } \\
\text { duration of exposure }\end{array}$ & 6 \\
\hline Malaysia & $\begin{array}{l}\text { Total (NR): exposed } \\
\text { (exp): } 10 \text {, control } \\
\text { (ctr): } 0.2\end{array}$ & $32(N R)$ & Office & No & NR & $\begin{array}{l}\text { Non-smoking exposed vs } \\
\text { non-smoking ctr: FEV } / \text { FVC } \\
\text { ratio: } 92(0.7) \text { vs } 84(2.1)\end{array}$ & 7 \\
\hline Taiwan & $\begin{array}{l}\text { Respirable: exp } \\
\text { (147): } 3.6 \text { (4.9), ctr } \\
\text { (51): } 0.41(0.98)\end{array}$ & $147(100)$ & Office & Yes & $\begin{array}{l}\text { OR for cough: } 1.6(1.3 \text { to } 1.8) \text {, } \\
\text { phlegm: } 1.3(1.1 \text { to } 1.5) \text {, wheezing: } \\
1.2(1.0 ; 1.4) \text {, dyspnoea: } 1.2(1.1 \\
\text { to } 1.4)\end{array}$ & $\begin{array}{l}\text { FEV }_{1}: 2.7 \text { L vs } 3.0, p<0.05 \\
\text { FVC: } 3.5 \text { L vs } 3.8(p<0.05)\end{array}$ & 8 \\
\hline Jordan & $\begin{array}{l}\text { Respirable (65): low: } \\
0.5 \text { (2.1), medium: } \\
1.6(2.6) \text { high: } 3.9 \\
(4.0)\end{array}$ & $348(58)$ & Low-exposed & Yes & $\begin{array}{l}\text { Increased prevalence of } \\
\text { symptoms, }\end{array}$ & $\begin{array}{l}\text { NS differences in lung } \\
\text { function in the three groups }\end{array}$ & 9 \\
\hline $\begin{array}{l}\text { Saudi } \\
\text { Arabia }\end{array}$ & $\begin{array}{l}\text { Respirable (97): } \\
2.1-60\end{array}$ & $72(48)$ & Office & Yes & $\begin{array}{l}\text { OR for wheezing: } 1.2(1.0 \text { to } 1.4) \text {, } \\
\text { dyspnoea: } 2.9(1.0 \text { to } 7.0) \text {, asthma: } \\
1.2 \text { (1.1 to } 1.4)\end{array}$ & NR & 10 \\
\hline Tanzania & $\begin{array}{l}\text { Total }(120): \mathrm{mg} / \mathrm{mg}^{3} \times \\
\text { year: exp: } 69(3.9) \text {, } \\
\text { ctr: } 11(2.8)\end{array}$ & $126(100)$ & Blue-collar, office & Yes & NR & $\begin{array}{l}>300 \mathrm{mg} / \mathrm{m}^{3} \text { vs }<100 \\
\text { associated with } \mathrm{FEV} \mathrm{V}_{1} / \mathrm{FVC} \\
<0.7: \text { OR } 9.9(3.5 \text { to } 28)\end{array}$ & 11 \\
\hline Tanzania & $\begin{array}{l}\text { Total (120): exp: } 13 \\
\text { (10), ctr: } 1.5 \text { (2.1) }\end{array}$ & $120(95)$ & $\begin{array}{l}\text { Blue-collar, } \\
\text { low-exposed, office }\end{array}$ & Yes & $\begin{array}{l}\text { OR for chronic cough: } 4.5 \text { ( } 1.9 \text { to } \\
\text { 10), chronic sputum: } 4.8 \text { (1.6 to } \\
\text { 14), chronic bronchitis: } 5.5 \text { (2.0 to } \\
\text { 15), chronic obstructive respiratory } \\
\text { disease: } 19(10) \% \text { vs } 1.5(2.1) \%\end{array}$ & NR & 12 \\
\hline Tanzania & $\begin{array}{l}\text { High exposed: } \\
\text { respirable }(30): 4 \\
\text { (3.3), low: } 0.7(0.6)\end{array}$ & $84(97)$ & $\begin{array}{l}\text { Blue-collar } \\
\text { low-exposed, office }\end{array}$ & Yes & $\begin{array}{l}\text { Exposure } \geq 2 \mathrm{mg} / \mathrm{m}^{3} \text { associated } \\
\text { with cough: OR } 7.9 \text { (1.8 to } 35) \text {, } \\
\text { dyspnoea: } 4.2 \text { ( } 1.1 \text { to } 15)\end{array}$ & $\begin{array}{l}\text { Peak expiratory flow: } 4.5 \% \\
\text { decrease per unit } \\
\text { log-transformed dust }\end{array}$ & 13 \\
\hline Tanzania & $\begin{array}{l}\text { Total (137): exp: } 5.0 \\
\text { (3.2), ctr: } 0.6(1.3)\end{array}$ & $102(82)$ & Blue-collar & $\begin{array}{l}\text { Smokers } \\
\text { excluded, no } \\
\text { adj. for age }\end{array}$ & $\begin{array}{l}\text { Fraction of exhaled nitric oxide: NS } \\
\text { differences exp vs ctr }\end{array}$ & NR & 14 \\
\hline Iran & & $88(100)$ & Office & No & & & 15 \\
\hline
\end{tabular}




\section{Table 1 Continued}

\begin{tabular}{|c|c|c|c|c|c|c|c|}
\hline Country & $\begin{array}{l}\text { Exposure metric } \\
\text { (number), personal } \\
\text { dust levels } \mathrm{mg} / \mathrm{m}^{3} \\
\text { (SD) }\end{array}$ & $\begin{array}{l}\text { Number of } \\
\text { exposed } \\
\text { workers } \\
\text { (response } \\
\text { rate, \%) }\end{array}$ & $\begin{array}{l}\text { Source of } \\
\text { controls }\end{array}$ & $\begin{array}{l}\text { Adjustment } \\
\text { for age and } \\
\text { smoking }\end{array}$ & $\begin{array}{l}\text { Main effects respiratory } \\
\text { symptoms and other findings: } \\
\text { OR }(95 \% \mathrm{Cl}) \text { or percentage (SD) } \\
\text { exposed vs non-exposed, } \\
\text { p value }\end{array}$ & $\begin{array}{l}\text { Main effects lung function } \\
\text { tests: OR }(95 \% \mathrm{Cl}) \text { or } \\
\text { percentage }(\mathrm{SD}) \text { exposed } \\
\text { vs non-exposed, } p \text { value }\end{array}$ & Reference \\
\hline & $\begin{array}{l}\text { Inhalable dust (NR): } \\
53(43) \text {, respirable } \\
\text { (NR): } 26 \text { (14) }\end{array}$ & & & & $\begin{array}{l}\text { Prevalence exposed vs ctr: cough: } \\
32 \% \text { vs } 20 \% \text { ( } p=0.04) \text {, phlegm: } \\
26 \% \text { vs } 15 \%(p=0.03) \text {, dyspnoea: } \\
17 \% \text { vs } 5 \%(p=0.006) \text {, wheeze: } \\
28 \% \text { vs } 5 \%(p<0.0001)\end{array}$ & $\begin{array}{l}\text { FEV } 1 / \text { FVC: } 104 \text { (9.2) vs } \\
105(11) \\
\text { FVC\% predicted: } 88 \text { (25) vs } \\
109(27)\end{array}$ & \\
\hline Iran & $\begin{array}{l}\text { Respirable (139): } \\
\text { exp: } 5.4-30 \text { ctr: } 0.9\end{array}$ & $94(100)$ & Office & No & NS & $\begin{array}{l}\text { FEV } 1 / F V C: 0.79 \text { vs } 0.82 \\
(p=0.006), F V C: 3.9 \text { vs } 4.2 \\
(p=0.006)\end{array}$ & 16 \\
\hline $\mathrm{UAE}^{\star *}$ & Total (NR): $4.5-15$ & $149(100)$ & Office & Yes & $\begin{array}{l}\text { OR for cough: } 12(1.5 ; 13) \\
\text { phlegm: } 15(1.8 ; 101)\end{array}$ & NR & 17 \\
\hline Europe & $\begin{array}{l}\text { Thoracic aerosol: } \\
\text { group median }(2670) \text { : } \\
0.85(4.6), \text { lowest } \\
\text { quartile: }<0.49 \\
\text { highest: }>1.73\end{array}$ & 4265 (NR) & $\begin{array}{l}\text { Office. } \\
\text { low-exposed }\end{array}$ & Yes & $\begin{array}{l}\text { OR for symptoms range: } 1.2-2.6 \text { in } \\
\text { highest quartile vs lowest quartile } \\
\text { of exposure }\end{array}$ & $\begin{array}{l}\text { Reduced } \mathrm{FEV}_{1}: 0.27(0.19 \\
\text { to } 0.30) \text { in highest vs lowest } \\
\text { level of exposure }\end{array}$ & 18 \\
\hline Tanzania* & $\begin{array}{l}2002 \text { (79): Total: } \\
1.4-56 \\
2010 \text { (179): Total: } \\
1.1-20\end{array}$ & $\begin{array}{l}\text { 2002: } 120 \\
\text { 2010: } 171 \text { (82) }\end{array}$ & $\begin{array}{l}\text { Blue-collar } \\
\text { low-exposed, office }\end{array}$ & Yes & $\begin{array}{l}\text { OR for chronic bronchitis in } 2002 \\
\text { vs } 2010: 5.5(2.0 \text { to } 15) \text { vs } 0.5 \\
\text { (0.2 to } 2.0), p=0.02\end{array}$ & $\begin{array}{l}\text { FEV }_{1} / \text { FVC: } 0.77(0.6) \text { vs } \\
0.83(0.1), p<0.001, \text { FVC: } \\
95 \text { (13) vs } 111(17) \\
p<0.001\end{array}$ & ${ }^{19} \dagger$ \\
\hline
\end{tabular}


Table 2 Characteristics and main results of included cohort studies assessing non-malignant respiratory disease and exposure to cement production dust

Main effects lung

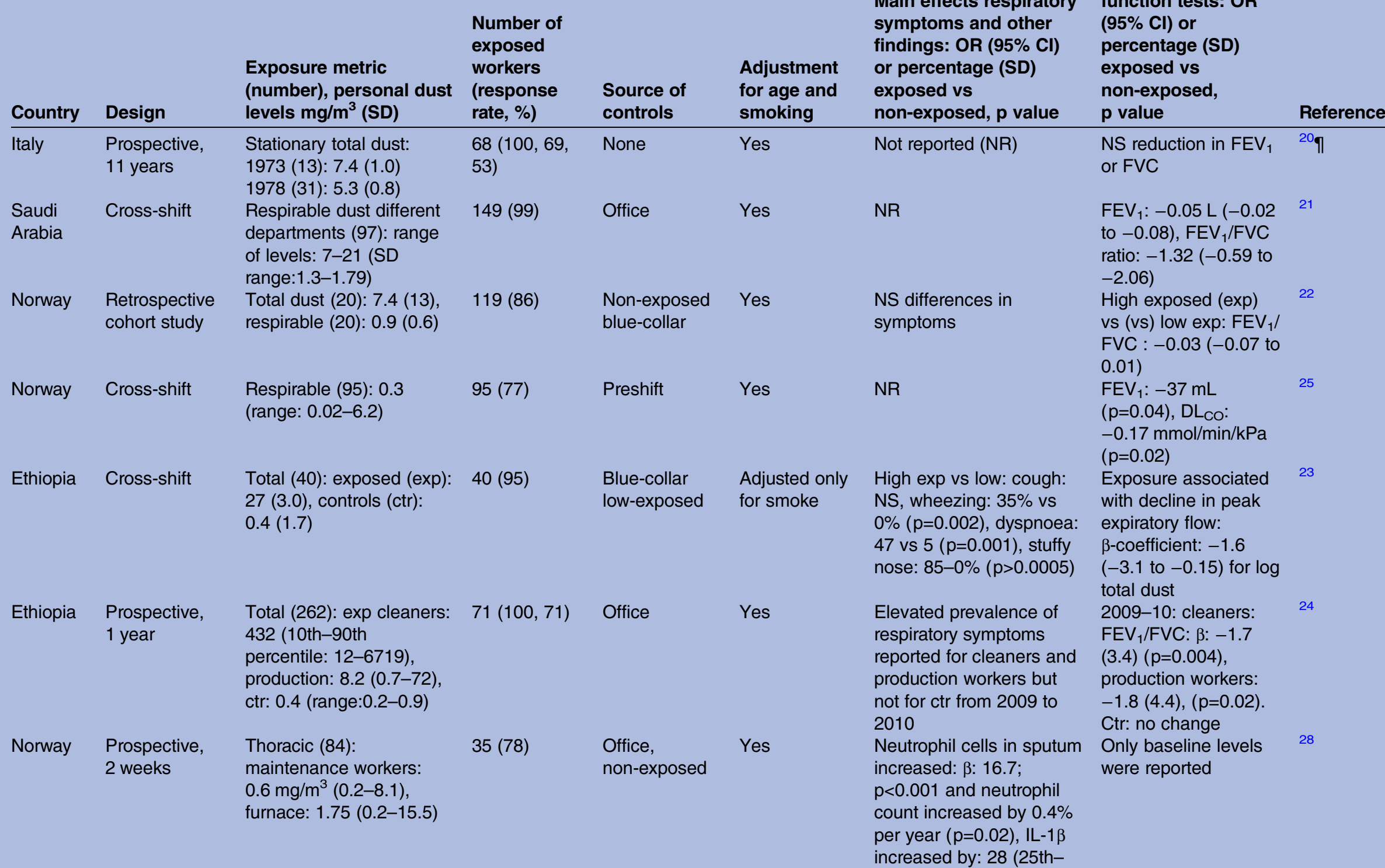


Table 2 Continued

\begin{tabular}{|c|c|c|c|c|c|c|c|c|}
\hline Country & Design & $\begin{array}{l}\text { Exposure metric } \\
\text { (number), personal dust } \\
\text { levels } \mathrm{mg} / \mathrm{m}^{3} \text { (SD) }\end{array}$ & $\begin{array}{l}\text { Number of } \\
\text { exposed } \\
\text { workers } \\
\text { (response } \\
\text { rate, \%) } \\
\end{array}$ & $\begin{array}{l}\text { Source of } \\
\text { controls }\end{array}$ & $\begin{array}{l}\text { Adjustment } \\
\text { for age and } \\
\text { smoking }\end{array}$ & $\begin{array}{l}\text { Main effects respiratory } \\
\text { symptoms and other } \\
\text { findings: OR }(95 \% \mathrm{Cl}) \\
\text { or percentage (SD) } \\
\text { exposed vs } \\
\text { non-exposed, p value }\end{array}$ & $\begin{array}{l}\text { Main effects lung } \\
\text { function tests: OR } \\
\text { (95\% Cl) or } \\
\text { percentage (SD) } \\
\text { exposed vs } \\
\text { non-exposed, } \\
\text { p value } \\
\end{array}$ & Reference \\
\hline & & & & & & $\begin{array}{l}\text { 75th percentile: } 21-36) \text { vs } \\
17 \mathrm{pg} / \mathrm{mL}(13-21)\end{array}$ & & \\
\hline Iran & Cross-shift & $\begin{array}{l}\text { Total (148): exp: 17, } \\
\text { ctr: } 0.9\end{array}$ & $100(100)$ & Office & Yes & $\begin{array}{l}\text { Stuffy nose: } 52 \% \text { vs } 6 \% \\
\text { ( } p<0.001), \text { dyspnoea: } \\
49 \% \text { vs } 2 \%(p<0.00)\end{array}$ & $\begin{array}{l}\text { FEV } 1 \text { FVC: } \beta:-0.8 \\
(-3.9 \text { to }-3.1), \text { FVC: } \\
\beta:-0.7(-3.1 \text { to }-2.3)\end{array}$ & 26 \\
\hline Denmark & $\begin{array}{l}\text { Retrospective } \\
\text { cohort study }\end{array}$ & $\begin{array}{l}\text { Total dust (105): } 3.3 \\
\text { (25th and } 75 \text { th quartiles: } \\
2.0 ; 7.8) \text {, respirable : } 1.5 \\
(1.0 ; 2.2)\end{array}$ & $546(89)$ & $\begin{array}{l}\text { General } \\
\text { population }\end{array}$ & Yes & $\begin{array}{l}\text { Hospitalisation due to } \\
\text { chronic obstructive } \\
\text { pulmonary disease: } 1- \\
10 \text { year exp: OR } 1.2(0.5 \\
\text { to } 2.7), 11-20 \text { year: } 1.3 \\
(0.5 \text { to } 3.4), 21-30 \text { year: } \\
1.6(0.8 \text { to } 3.4),<30 \text { year: } \\
1.0(0.4 \text { to } 2.6)\end{array}$ & $\begin{array}{l}\text { Only baseline levels } \\
\text { were reported }\end{array}$ & 27 \\
\hline Tanzania & $\begin{array}{l}\text { Prospective, } 1 \\
\text { year }\end{array}$ & $\begin{array}{l}\text { Total: } 2010 \text { (126): } 5.0 \\
\text { (range: } 0.6-69), 2011 \\
\text { (52): } 7.4(0.3-110)\end{array}$ & $134(81,78)$ & Office & Yes & $\begin{array}{l}\text { Prevalence } 2010 \text { vs } 2011 \\
\text { of cough: } 21 \% \text { vs } 12 \% \\
\text { ( } p<0.05) \text {, cough with } \\
\text { sputum: } 19 \% \text { vs } 10 \% \\
\text { ( } p<0.05) \text {, dyspnoea: } 14 \% \\
\text { vs } 2 \%(p<0.01) \text {, wheeze: } \\
24 \% \text { vs } 7 \%(p<0.001)\end{array}$ & NR & 29 \\
\hline Europe & $\begin{array}{l}\text { Prospective, } \\
4 \text { years }\end{array}$ & $\begin{array}{l}\text { Thoracic }(6111) \text { : } \\
\text { non-administration; varied } \\
\text { between job types and } \\
\text { plants: } 0.09-14.6 \mathrm{mg} / \mathrm{m}^{3}\end{array}$ & 4966 (NR) & $\begin{array}{l}\text { Low-exposed } \\
\text { workers }\end{array}$ & Yes & NR & $\begin{array}{l}\mathrm{FEV}{ }_{1} / \mathrm{m}^{2} \text { per }(\mathrm{mg} / \\
\left.\mathrm{m}^{3}\right) \times y e a r:-3.8 \mathrm{~mL} \\
(-7.0 \text { to }-0.7) \text { for } \\
2.25-3.35 \mathrm{mg} / \mathrm{m}^{3} \text {, and } \\
-7.4(-10.7 \mathrm{to}-4.2) \\
\text { for } 3.36-14.6 \mathrm{mg} / \mathrm{m}^{3}\end{array}$ & 30 \\
\hline
\end{tabular}


assessed. ${ }^{14}$ No differences in FeNO concentrations were detected.

Two studies from Iran reported reduced $\mathrm{FEV}_{1} / \mathrm{FVC}$ and reduced FVC levels in exposed workers compared with office workers. ${ }^{15}{ }^{16}$ High crystalline silica levels were reported in these two cement plants, amounting to $27 \%$ and $22 \%$ of the dust, respectively. Thus, the effects of crystalline silica exposure need to be considered as confounders in these studies. In a study from 2012 conducted among cement production workers in the UAE, elevated ORs for cough and phlegm were detected. ${ }^{17}$ That study collected only total dust samples and used office workers as references.

In the first cross-sectional analysis from a prospective study, our research group assessed lung function and respiratory symptoms among 4265 cement production workers from 24 plants in 8 European countries (Estonia, Greece, Italy, Norway, Spain, Sweden, Switzerland and Turkey). ${ }^{18}$ ORs were elevated for symptoms and airflow limitation in the higher levels of exposure, using the lowest quartile of exposure as reference. $\mathrm{FEV}_{1} / \mathrm{FVC}$ decreased with age and the prevalence of airflow limitation increased with age, by the use of either $\mathrm{FEV}_{1} / \mathrm{FVC}<0.7$ or $\mathrm{FEV}_{1} / \mathrm{FVC}<$ lower limit of normal (LLN). FEV 1 showed an exposure-response relationship with a $270 \mathrm{~mL}$ deficit (95\% CI 190 to $300 \mathrm{~mL}$ ) in the highest compared with the lowest exposure level. In 2014, Tungu et $a l^{19}$ compared two cross-sectional studies from the same cement plant in Tanzania. Total dust exposure was lower in the second study conducted from 2010 to 2011 than in the first during 2002. Corresponding to the reduced dust levels, there was lower prevalence of chronic respiratory symptoms and higher dynamic lung volumes among cement workers in 2010 compared with 2002.

\section{Cohort studies}

Eight out of 11 cohort studies report reduced lung function in exposed workers when compared with controls. In a study following 68 Italian cement workers from 1973 to 1984 , small, non-significant reductions in FVC and $\mathrm{FEV}_{1}$ for all workers were detected over the follow-up period. ${ }^{20}$ However, that study did not include a control group. Ali et $a l^{21}$ investigated changes in pulmonary function during work shifts among workers in Saudi Arabian cement plants. The mean reductions in $\mathrm{FEV}_{1}$, $\mathrm{FEV}_{1} / \mathrm{FVC}$ ratio and $\mathrm{FEF}_{25-75 \%}$ were significantly greater in the high-level exposed workers than in unexposed controls. These readings were unadjusted for height and socioeconomic status.

In a retrospective cohort study of 119 present and former employees and 50 blue-collar referents from a cement plant in Norway, we used a system for weighting previous exposure based on interviews with a group of 18 long-term workers (ie, a focus group). ${ }^{22}$ We observed similar prevalence of symptoms, mean pulmonary function indices and prevalence of COPD in exposed workers and referents. High FVC levels among exposed workers indicated the presence of healthy worker effects, whereas $\mathrm{FEV}_{1} / \mathrm{FVC}$ showed a slight tendency towards lower levels in the highest exposed group.

A small Ethiopian cross-shift study detected cross-shift reductions in PEF, which were most pronounced among high-level exposed workers. ${ }^{23}$ A high prevalence of respiratory symptoms was reported among workers exposed to high levels of cement dust during production. Dust levels were associated with increased crossshift decrease in PEF. The study sample was small and the analyses were not adjusted for age. In another Ethiopian study, 71 cement production workers were followed for 1 year. $^{24}$ Increased prevalence of morning cough, cough with sputum and lower lung function indices were demonstrated among high-exposed workers compared with workers with low exposure. Extremely high levels of total dust exposure were measured in that study, showing a geometric mean of $432 \mathrm{mg} / \mathrm{m}^{3}$ (10th90th percentile: 12-6710) among cleaners and $8.2 \mathrm{mg} /$ $\mathrm{m}^{3}(0.7-72)$ among production workers. It is not clear whether these levels reflect the actual dust levels in the plant. No adjustment for smoking was performed.

In 2010, we reported a cross-shift study of 95 workers from 2 cement plants in Norway. $^{25}$ Workers were assessed with spirometry, gas diffusion, FeNO measurements and blood sampling at baseline (before the work shift), after the shift and again 32 hours after the baseline measurements. We observed reductions in $\mathrm{FEV}_{1}$, $\mathrm{FEF}_{25-75 \%}$, DL $\mathrm{CO}$ and FeNO levels, corresponding to increased numbers of leucocytes, elevated levels of fibrinogen and tumour necrosis factor $\alpha$ and reduced levels of IL-10. The only association identified between the exposure measurements and outcome variables was between the baseline level of fibrinogen and the highest respirable aerosol level $\left(>0.4 \mathrm{mg} / \mathrm{m}^{3}\right)$, which was elevated by $0.39 \mathrm{~g} / \mathrm{L}(95 \%$ CI 0.06 to 0.72$)$.

In a recent study from Iran of 200 workers, increased prevalence of respiratory symptoms and reduced lung function indices were reported postshift. ${ }^{26}$ Multivariate analysis demonstrated an association between these changes and exposure to cement production dust. However, it is not clear whether the 100 low-exposed and 100 high-exposed workers were randomly selected or whether all workers volunteered for the study. In a study of long-term exposure to cement dust and later hospitalisation with respiratory disease, 546 Danish cement production workers were compared with other blue-collar workers $(n=847)$ and with the general population. ${ }^{27}$ Cement workers did not have an increased rate of hospitalisation during the 10-year follow-up period compared with controls. Nevertheless, a tendency towards increasing rates of hospitalisation due to COPD was observed with increasing duration of exposure up to 30 years. Thereafter, hospitalisation rates declined.

Our group also conducted a study in which 35 healthy dust-exposed, non-smoking cement production workers performed induced sputum measurements and spirometry after a period of exposure and again after 5 days 
without work or exposure. ${ }^{28}$ An external control group (students and hospital workers) and an internal reference group of non-exposed or very low-exposed workers were established (29 and 15 workers, respectively). A significantly higher percentage of neutrophil cells in sputum was observed in cement production workers after the exposure period compared with internal and external reference groups. The elevated percentage of neutrophils corresponded to an increased level of IL- $1 \beta$ in sputum.

In 2015, a 1-year follow-up of respiratory symptoms among 134 Tanzanian cement production workers and 63 controls detected significantly lower prevalence of cough, cough with sputum, dyspnoea and wheeze among exposed workers assessed before and after a campaign promoting the use of personal respiratory protection equipment. ${ }^{29}$ There were no changes in symptom prevalence among the controls and total dust exposure levels among exposed workers did not differ between the two time points. In a recent prospective study, we report results from a 4-year follow-up of 4966 employees of 24 cement production plants in 8 countries. ${ }^{30}$ Personal measurements of thoracic dust for eight job categories were collected, lung function measurements performed and questionnaires completed at baseline, and at follow-up. The arithmetic mean (AM) exposure level among non-administration employees was estimated from group-based analysis of the measurement results, showing variation between job types and plants from 0.09 to $14.6 \mathrm{mg} / \mathrm{m}^{3}$. Exposure was associated with a reduction in forced expiratory volumes in a doseresponse manner. Based on the estimated declines of $\mathrm{FEV}_{1} / \mathrm{m}^{2}$, for a person of $1.75 \mathrm{~m}$ standing height (median persons height), a $12.2 \mathrm{~mL} / \mathrm{m}^{2}$ decline in the comparison group and 3.8 and $7.4 \mathrm{~mL} / \mathrm{m}^{2}$ excess decline in $\mathrm{FEV}_{1}$ in the fourth and fifth exposure quintile equals 37, 12 and $22 \mathrm{~mL}$ annual declines in $\mathrm{FEV}_{1}$ for these groups, respectively. For $\mathrm{FEV}_{1} / \mathrm{FVC}$, a significant reduction was observed in the highest exposure level compared with the lowest level.

\section{DISCUSSION}

Fifteen cross-sectional and 11 cohort studies addressing the association between exposure and non-malignant respiratory effects in the cement production workers were identified. In cross-sectional studies, ORs for symptoms ranged from 1.2 to 4.8 , while $\mathrm{FEV}_{1} / \mathrm{FVC}$ was $1-6 \%$ lower in the exposed than in controls suggesting a small effect only. Larger effects were reported in cohort studies, which detected a yearly excess decline in $\mathrm{FEV}_{1} /$ FVC ranging from $0.8 \%$ to $1.7 \%$ for exposed workers.

One of the cross-sectional studies did not include a reference population, ${ }^{6}$ three failed to adjust for smoking $^{715^{16}}$ and four did not adjust for age ${ }^{74-16}$ as potential confounding variables. Two cross-sectional studies with relevant reference populations failed to demonstrate differences in the spirometric measurements between workers and referents. ${ }^{5} 9$ Exposure levels reported in studies from the former Yugoslavia, ${ }^{6}$ Malaysia, ${ }^{7}$ Taiwan, ${ }^{8}$ Jordan, ${ }^{9}$ Saudi Arabia,${ }^{10}$ Tanzania, ${ }^{11-14} \operatorname{Iran}^{15}{ }^{16}$ and the $\mathrm{UAE}^{17}$ were twofold or higher than in cement production plants in the USA. ${ }^{5}$ The use of total dust levels in several studies probably does not provide a precise estimate of inhaled particles that deposit in the lower airways. ${ }^{31} 32$ Thus, these studies may have been hampered by exposure misclassification, diluting the observed associations between exposure and outcomes. At present, occupational exposure limits for respirable dust of $5 \mathrm{mg} / \mathrm{m}^{3}$ and total dust of $10 \mathrm{mg} / \mathrm{m}^{3}$ are commonly used.

The European cross-sectional study from 2011 demonstrated for the first time an exposure-response relationship for $\mathrm{FEV}_{1}$ among workers with the highest exposure levels compared with workers with the lowest exposure levels. ${ }^{28}$ Important strengths of that study were sample size $(\mathrm{N}=4265)$, the use of $\mathrm{LLN}$ in addition to $\mathrm{FEV}_{1} / \mathrm{FVC}$ ratio to estimate airflow limitation and the use of comprehensive exposure data $(\mathrm{N}=2670)$. However, using the cross-sectional design, selection in or out of the population could not be controlled, which may have resulted in biased estimates. Among the included cross-sectional studies, there were large differences between dust levels, methods used and findings. Consequently, these studies cannot form the basis for a consensus regarding safe levels of worker exposure.

A limited number of cohort studies were identified of which 6 out of 11 had very short follow-up times ranging from a single work shift to a year. The first cohort study from 1988 had a follow-up time of 11 years, but included only 68 workers and no control group. ${ }^{20}$ The second cohort study published in 1998 included 149 exposed workers, but did not adjust for height. ${ }^{21}$ In addition, confounding due to differences in socioeconomic status between groups was likely. In the first Norwegian study from 2003, no differences in respiratory symptoms or lung function indices between exposed worker and bluecollar controls were detected. ${ }^{22}$ The results were adjusted for possible confounders, and assessment of current and previous exposure was included. However, workers from an ammonium plant were used as references because they were presumably unexposed to ammonia as the plant had a closed production process. Nevertheless, rest-confounding due to background exposure in the control plant may have occurred, resulting in underestimation of effects.

The first Ethiopian cohort study published in 2010 assessed only PEF, had a small sample size $(\mathrm{N}=40)$ and did not adjust for age. ${ }^{23}$ The second Ethiopian study was larger $(\mathrm{N}=100)$, but had a follow-up of only 1 year, was unadjusted for smoking and the extremely high dust levels recorded may not reflect actual levels. ${ }^{24}$ Thus, these findings should be interpreted with caution. A Norwegian cross-shift study detected changes of inflammatory markers and lung function in exposed workers when compared with controls, but the only significant 
association between exposure and outcome was for fibrinogen. ${ }^{25}$ Thus, further studies are needed to confirm these findings. Another cross-shift study included 100 Iranian cement production workers, a control group of office workers and was adjusted for age and smoking; however, only total dust was measured and not respirable or thoracic dust fractions. ${ }^{26}$ Moreover, the inclusion criteria were unclear; if workers with respiratory symptoms were over-represented, this may have resulted in overestimation of the effects.

One study assessed hospitalisation among 546 Danish cement production workers. ${ }^{27}$ That study included crude levels of $\mathrm{FEV}_{1}$, and adequate adjustment for possible confounders. Cement workers did not have an increased rate of hospitalisation during the 10-year follow-up period compared with controls. Nevertheless, there was a tendency towards increasing rates of hospitalisation due to COPD observed with increasing duration of exposure up to 30 years. Thereafter, the hospitalisation rates declined, probably due to a healthy worker effect.

The only study assessing inflammatory changes in induced sputum samples showed elevated percentage of blood neutrophils corresponding to an increased level of IL-1 $\beta$ in sputum. ${ }^{28}$ That study included internal (lowlevel exposed office workers) and external controls (healthy non-exposed volunteers), but no associations between the exposure measurements and inflammatory cells or markers were detected. Thus, it is unclear whether the findings were markers of exposure or signs of airway inflammation.

Interestingly, a Tanzanian study from 2015 showed a lower prevalence of respiratory symptoms among exposed workers assessed before and after a campaign promoting the use of personal respiratory protection equipment. ${ }^{29}$ That study is important because it assessed the effects of an intervention. It did not, however, include lung function measurements; hence, it is not clear whether improvements in workers' lung function were achieved.

One of the inclusion criteria for this review was exposure measurements, but only few studies used this information to evaluate dose-response relationships. Most studies simply assessed associations between exposed workers and controls. In the first cross-sectional phase of our study of 24 plants, we observed a dose-response relationship for $\mathrm{FEV}_{1}$ levels, with $270 \mathrm{~mL}$ lower levels of $\mathrm{FEV}_{1}(95 \%$ CI 190 to $300 \mathrm{~mL})$ estimated for workers with the highest exposure levels compared with workers with the lowest exposure levels. ${ }^{18}$ These results were confirmed at the 4-year follow-up, which demonstrated an annual excess decline of $7.4 \mathrm{~mL} / \mathrm{m}^{2}$ for exposure in the highest category, compared with the lowest category for $\mathrm{FEV}_{1} / \mathrm{m}^{2}{ }^{30}$ We demonstrated, in both studies in which thoracic aerosol fraction were measured, that at each level of increasing exposure, there is an increased effect compared with the previous level. The dose-response relationships demonstrated in these studies may indicate a causal relationship between exposure and outcome.
Based on 6111 thoracic aerosol samples from 2534 workers included in the prospective European study, ${ }^{30}$ Notø et $a l^{33}$ showed that adjusted geometric means of thoracic aerosol varied between job types from 0.20 to $1.2 \mathrm{mg} / \mathrm{m}^{3}$ when the mean was calculated for each job type across plants. The highest exposure levels were observed for the production, cleaning and maintenance workers $\left(0.8-1.2 \mathrm{mg} / \mathrm{m}^{3}\right)$ and could reach levels at which the risk of lung function loss may be elevated. The relationships between thoracic aerosol and other health-related aerosol fractions in the cement production industry were estimated in a recent study. ${ }^{34}$ The predicted median ratios of the aerosol fractions in that study were $0.51,2.4$ and 5.9 for respirable/thoracic, total/thoracic and inhalable/thoracic fractions, respectively. It was shown that if these fractions are multiplied with the lowest exposure level found to be associated with longitudinal lung function decline $(1.56-2.24 \mathrm{mg}$ / $\mathrm{m}^{3}$ ) in the European longitudinal study, ${ }^{30}$ estimated lowest levels of effect will equal $0.8-1.1 \mathrm{mg} / \mathrm{m}^{3}$ for respirable dust, $3.7-5.4 \mathrm{mg} / \mathrm{m}^{3}$ for total dust and $9.2-$ $13 \mathrm{mg} / \mathrm{m}^{3}$ for inhalable dust. For respirable and total dust, these levels of observed effect are clearly below the present occupational exposure limits, suggesting that these limits are not protective.

There are several important, limitations of our review. First, we did not use the GRADE criteria, or any other similar criteria to evaluate the level of evidence of the included studies. These criteria are well suited for assessment of clinical trials, but have limitations when it comes to epidemiological data because all observational studies are graded providing a low or very low degree of evidence. However, we have included information regarding study design, if and how covariates were assessed, inclusion of reference participants and a section in the text regarding dose-response evaluations. This, to some degree, allows the assessment of the quality of the included studies. If non-positive studies assessing respiratory health were not published, and thus not included in this review, publication bias may have occurred. However, this concern is ameliorated by the fact that non-positive studies were identified. ${ }^{5} 22$ Assessment of publication bias through a funnel plot was not considered meaningful, because many of the 15 cross-sectional studies, did not include controls, adjust for smoking and/or include variance of the outcome estimates.

Our search strategy may have been incomplete. The so-called 'grey literature' was assessed through Google Scholar, but no further studies fulfilling the inclusion criteria were detected. Another possible bias is selective reporting within the included studies. The quality of the included studies varied. Although we have examined the included studies with reporting bias in mind, assessment was difficult due to lack of protocol descriptions in the published reports and other limited information, especially in older studies.

One of the primary difficulties when comparing results across studies is the difference in outcome 
definitions. Most of the included studies reported FVC, $\mathrm{FEV}_{1}$ levels and the $\mathrm{FEV}_{1} / \mathrm{FVC}$ ratio, but some reported only crude values, whereas others reported only per cent of predicted. Few studies include information about the prediction equations used to calculate expected values. We identified only one study that reported the LLN. ${ }^{18}$ Another major difficulty in reviewing the literature was the non-comparability of exposure assessments between studies. We restricted the review to those studies reporting dust measurements, but limited information was available regarding sampling and quality of measurements (eg, type of equipment, calibration of pumps, weighing of the filters, weather conditions and grouping of measurements). Furthermore, different fractions of dust were measured (ie, total, respirable, inhalable and thoracic). To allow assessment of these differences across studies, information regarding the type and level of exposure measurement is included in tables 1 and 2. In addition, adjustment for potential confounders varied between studies. We considered applying stricter inclusion criteria, but this strategy would have left a limited number of references for review. Thus, we chose to include studies that lacked control groups and/or did not use proper adjustments for potential confounders. Additional studies are needed to further explore the mechanisms and pathways of airway inflammation and non-malignant respiratory effects of exposure to dust generated during cement production. Researchers conducting future studies should also consider including measurement of $\mathrm{C}$ reactive protein and fibrinogen levels, to investigate the systemic effects of exposure to cement dust as a risk factor for cardiovascular disease.

Reduced exposure to cement dust through exposure control measures is the most important and primary means of preventing airflow limitation and inflammatory changes among cement production workers. Primary prevention of respiratory effects in the workplace can be achieved through exposure reduction by the use of technical and organisational measures. Until acceptable exposure levels are achieved, we recommend increased use of respiratory protective equipment in plants and areas of plants where high levels of exposure may occur. Secondary prevention of respiratory diseases in the cement production industry can be achieved through surveillance programmes and early detection. We recommend lung function testing and personal exposure assessments at regular intervals for those working in this industry.

In conclusion, cross-sectional studies show reduced lung function levels at or above $4.5 \mathrm{mg} / \mathrm{m}^{3}$ of total dust and $2.2 \mathrm{mg} / \mathrm{m}^{3}$ of respiratory dust. Few longitudinal data exist, but a large recent study has shown a doseresponse relationship between dust exposure and decline in lung function indices, with an annual decline of $7.4 \mathrm{~mL} / \mathrm{m}^{2}$ in the highest exposure category, compared with the lowest category for $\mathrm{FEV}_{1} / \mathrm{m}^{2}$. Indications of subclinical airway inflammation in cement production workers are demonstrated in the published literature. One study reported signs of airway inflammation in induced sputum and two studies have demonstrated small increases in FeNO levels within a work shift, but further research is needed to identify the mechanisms of these observed effects.

Acknowledgements The authors are grateful to Mirjam Håndlykken and Jane Andreassen at the Medical Library, Telemark Hospital, Skien, Norway, for their excellent guidance and help with the search strategy and implementation.

Contributors AKMF and KCN contributed to the conception and design of the study, and to the assessment of the included articles. Both authors contributed to the interpretation of data and drafting of the manuscript.

Funding Telemark Hospital and the National Institute of Occupational Health funded the work of the first and the second authors, respectively.

Competing interests None declared.

Provenance and peer review Not commissioned; externally peer reviewed.

Data sharing statement No additional data are available.

Open Access This is an Open Access article distributed in accordance with the Creative Commons Attribution Non Commercial (CC BY-NC 4.0) license, which permits others to distribute, remix, adapt, build upon this work noncommercially, and license their derivative works on different terms, provided the original work is properly cited and the use is non-commercial. See: http:// creativecommons.org/licenses/by-nc/4.0/

\section{REFERENCES}

1. Jaeger $\mathrm{H}$, Pelloni E. Positive skin tests with bichromates in cement eczema. Dermatologica 1950;100:207-16.

2. Bazas T. Effects of occupational exposure to dust on the respiratory system of cement production workers. J Soc Occup Med 1980;30:31-6.

3. Fairhurst S, Phillips A, Gilles C. Portland cement dust. Criteria for an occupational exposure limit. London: Health \& Safety Executive, 1994.

4. Guyatt $\mathrm{GH}$, Oxman AD, Akl EA, et al. GRADE guidelines: 1. Introduction-GRADE evidence profiles of findings and summary of findings in tables. J Clin Epidemiol 2011;64:383-94.

5. Abrons HL, Petersen MR, Sanderson WT, et al. Symptoms, ventilatory function, and environmental exposures in Portland cement workers. Br J Ind Med 1988;45:368-75.

6. Gomzi M, Stilinovic L, Godnic-Cvar J. Alpha ${ }_{1}$-antitrypsin and lung function in cement workers. Med Lav 1989;80:301-6.

7. Noor H, Yap CL, Zolkepli O, et al. Effect of exposure to dust on lung function of cement factory workers. Med J Malaysia 2000;55:51-7.

8. Yang CY, Huang CC, Chiu HF, et al. Effects of occupational exposure on the respiratory health of Portland cement workers. $J$ Toxicol Environ Health 1996;49:581-8.

9. AbuDhaise BA, Rabi AZ, al Zwairy MA, et al. Pulmonary manifestations in cement workers in Jordan. Int $J$ Occup Med Environ Health 1997;10:417-28.

10. Ballal SG, Ahmed HO, Ali BA, et al. Pulmonary effects of occupational exposure to Portland cement: a study from eastern Saudi Arabia. Int J Occup Environ Health 2004;10:272-7.

11. Mwaiselage J, Bråtveit M, Moen B, et al. Cement dust exposure and ventilatory function impairment: an exposure-response study. J Occup Environ Med 2004;46:658-67.

12. Mwaiselage J, Bråtveit M, Moen BE, et al. Respiratory symptoms and chronic obstructive pulmonary disease among cement factory workers. Scand J Work Environ Health 2005;31:316-23.

13. Mwaiselage J, Moen $\mathrm{B}$, Bråtveit $\mathrm{M}$. Acute respiratory health effects among cement factory workers in Tanzania: an evaluation of a simple health surveillance tool. Int Arch Occup Environ Health 2006;79:49-56.

14. Tungu $\mathrm{AM}$, Bråtveit $\mathrm{M}$, Mamuya $\mathrm{SH}$, et al. Fractional exhaled nitric oxide among cement factory workers: a cross-sectional study. Occup Med 2013;70:789-95.

15. Neghab M, Choobineh A. Work-related respiratory symptoms and ventilatory disorders among employees of a cement industry in Shiraz, Iran. J Occup Health 2007;49:273-8. 
16. Kakooei H, Gholami A, Ghasemkhani M, et al. Dust exposure and respiratory health effects in cement production. Acta Med Iran 2012;50:122-6.

17. Ahmed $\mathrm{HO}$, Abdullah AA. Dust exposure and respiratory symptoms among cement factory workers in the United Arab Emirates. Ind Health 2012;50:214-22.

18. Nordby KC, Fell AK, Notø $\mathrm{H}$, et al. Exposure to thoracic dust, airway symptoms and lung function in cement production workers. Eur Respir J 2011;38:1278-86.

19. Tungu AM, Bråtveit M, Mamuya $\mathrm{SH}$, et al. The impact of reduced dust exposure on respiratory health among cement workers: an ecological study. J Occup Environ Med 2014;56:101-10.

20. Siracusa A, Forcina A, Volpi R, et al. An 11-year longitudinal study of the occupational dust exposure and lung function of polyvinyl chloride, cement and asbestos cement factory workers. Scand $J$ Work Environ Health 1988;14:181-8.

21. Ali BA, Ballal SG, Albar AA, et al. Post-shift changes in pulmonary function in a cement factory in eastern Saudi Arabia. Occup Med 1998;48:519-22.

22. Fell AK, Thomassen TR, Kristensen $P$, et al. Respiratory symptoms and ventilatory function in workers exposed to Portland cement dust. $\mathrm{J}$ Occup Environ Med 2003;45:1008-14.

23. Zeleke ZK, Moen BE, Bråtveit M. Cement dust exposure and acute lung function: a cross shift study. BMC Pulm Med 2010; 10:19.

24. Zeleke ZK, Moen BE, Bråtveit M. Lung function and chronic respiratory symptoms among workers in the cement industry: a follow-up study. BMC Pulm Med 2011;11:50.

25. Fell AK, Notø $H$, Skogstad $M$, et al. A cross-shift study of lung function, exhaled nitric oxide and inflammatory markers in blood in
Norwegian cement production workers. Occup Environ Med 2011;68:799-805.

26. Aminian O, Aslani M, Sadeghniiat Haghighi K. Cross-shift study of acute respiratory effects in cement production workers. Acta Med Iran 2014;52:146-52.

27. Vestbo J, Rasmussen FV. Long-term exposure to cement dust and later hospitalization due to respiratory disease. Int Arch Occup Environ Health 1990;62:217-20.

28. Fell AK, Sikkeland LI, Svendsen MV, et al. Airway inflammation in cement production workers. Occup Environ Med 2010;67:395-400.

29. Tungu AM, Bråtveit M, Mamuya SD, et al. Reduction in respiratory symptoms among cement workers: a follow-up study. Occup Med 2015:65:57-60

30. Nordby KC, Notø H, Eduard W, et al. Thoracic dust exposure is associated with lung function decline in cement production workers. Eur Respir J 2016;48:331-9.

31. CEN. EN 481. Workplace atmospheres-size fraction definitions for measurements of airborne particles. Brussels: Comité Européen de Normalisation, 1993

32. Vincent JH. Framework for aerosol sampling in working, living and ambient environments. Aerosol Sampling, Science, Standards, Instrumentation, and Applications. Chichester: John Wiley \& Sons, 2007:221-307.

33. Notø $\mathrm{H}$, Nordby $\mathrm{KC}$, Kjuus $\mathrm{H}$, et al. Exposure to thoracic aerosol in a prospective lung function study of cement production workers. Ann Occup Hyg 2015;59:4-24.

34. Notø H, Nordby KC, Eduard W. Relationships between personal measurements of the respirable, thoracic, "total", and inhalable aerosol fractions in the cement production industry. AnnOccup Hyg 2016;60:453-66. 